\title{
Analysis of Genotype and Phylogenetic of Koi Herpesvirus (KHV) on Carp (Cyprinus carpio) in Lombok Island of West Nusa Tenggara Province Based on Thymidine Kinase Sequence
}

\author{
Amira Baihani ${ }^{1 *}$, Uun Yanuhar², Maftuch $^{3}$ \\ ${ }^{1}$ Master Program of Fisheries and Marine Sciences, Faculty of Fisheries and Marine Sciences, University of Brawijaya, \\ Malang, Indonesia \\ ${ }^{2}$ Faculty of Fisheries and Marine Sciences, University of Brawijaya, Malang, Indonesia
}

\begin{abstract}
Koi herpesvirus (KHV) is a virus that usually infects carp and koi causing mass mortality, as well as economic and social loss. The results of varied test are often found in its development. Allegedly, there are mutation or genetic variation of $\mathrm{KHV}$ in Indonesia. Based on these problems, this research aims to understand the genetic variation and kindship of KHV isolate in the carp (Cyprinus carpio) in Lombok Island of West Nusa Tenggara Province based on thymidine kinase sequence. Water quality of fish pond was checked. KHV clinical symptom was checked visually in each fish sample, then sacrifices the organ (gill) for PCR analysis and DNA sequencing. The research results show that clinical symptoms that appear are pale fish gill and bleeding on the surface of the body. The temperature in the research site shows an optimum range for KHV development. The results electrophoresis of carp suspected with KHV shows five positives out of a total six samples. Genetically, KHV isolates from Lombok Island of West Nusa Tenggara Province is identical with the GenBank isolate code KHV-J/U/I and Indo_OCO5WNT2.
\end{abstract}

Keywords: Carp, Koi herpesvirus, Phylogenetic, Thymidine kinase,.

\section{INTRODUCTION}

Koi herpesvirus (KHV) is a virus that usually infects carp and koi which lead to their mass death [1]. This virus was identified for the first time in 1998 as the cause of mass mortality of koi fish both juvenile and adult stages cultivated in Israel, United States and Germany [2,3]. KHV entered Indonesia in 2002 through cross-country fish trade [4].

This virus caused mass mortality which reached $80-95 \%$ population and has impacts of economic and social loss. This disease caused material loss about 15 billion rupiah in the first three months since the incidence of the disease on March to September 2002 [5]. KHV has been an outbreak in carp and koi almost all over Indonesia. According to the government of Republic of Indonesia, this disease has crossed spread almost all areas of carp farming in Indonesia [6].

Based on the result of the observation in 2016 by the Fish Quarantine Station of Quality Control and Safety Fishery Products Class II Mataram, it was found that quarantine pests and disease of fish in koi and carp namely Koi

\footnotetext{
* Correspondence address:

Amira Baihani

Email : amirabaihani20@gmail.com

Address : Faculty of Fisheries and Marine Sciences, University of Brawijaya, Veteran Malang, Malang 65145.
}

herpesvirus (KHV). Fish mortality amounted to \pm 1,992 fishes showed the mortality pattern that occurred quickly without showing any early symptom of fish disease attack. The review on KHV has been done by several researchers in several centers of cultivation in Lombok. The research results of their studies are the only incident report, until the detection phase using polymerase chain reaction (PCR) [7].

The results of varied test are often found in its development. Allegedly, there are mutation or genetic variation of KHV in Indonesia. According to Walker [8], genetic variation due to mutation of the nucleotide sequence can prevent the binding of primer PCR on the target sequence. Thorough research related to the amplicon sequencing KHV and the amount of geographic location variation of the genome's origin in the future will be useful in distinguishing some $\mathrm{KHV}$ isolates based on geographic location [8].

Koi herpesvirus (KHV) has and produces at least four genes encoding the same proteins expressed by the poxvirus: thymidylate monophosphate kinase, ribonucleotide reductase (RNR), thymidine kinase (TK) and B22R-like gene [9]. The use of conventional PCR based on the targeting of the thymidine kinase (TK) gene has been shown to be specific to KHV. The method distinguishes KHV (CyHV-3) from two other herpes viruses, CyHV-1 and CyHV-2 [10]. Based on differences in nucleotide sequence and insertion 
and deletion pattern among 3 CyHV-3 isolates obtained from Japan (KHV-J), US (KHV-U) and Israel (KHV-I), KHV forms two lineages: J lineage and $U / I$ [11].

Therefore, this research aims to determine the genetic and phylogenetic variation of Koi herpesvirus (KHV) in carp (C. carpio) in Lombok Island of West Nusa Tenggara based on sequence analysis of thymidine kinase. It provides the clues on growing variants and their pathogens related to the virus transmission pattern, thereby providing the information for both its prevention and control.

\section{MATERIALS AND METHODS}

The research conducted from March to April 2017 at the cultivation location in an area with the KHV epidemic occurrence. Location of cultivation pool of freshwater fish used in this research are Mataram, East Lombok, West Lombok and Central Lombok. The laboratory test conducted at the Fish Quarantine Test Laboratory, Quality Control and Safety Fishery Products Class II Mataram, Fish Quarantine Center, Quality Control and Safety of Fishery Product Class I Surabaya II and First Base Laboratories (molecular biology service) Malaysia.

Samples of fish that have been taken immediately examined of its clinical symptoms such as behavioral observation, and the appearance of the external or internal organs. Furthermore, the fish samples sent to the laboratory for analysis. Examination of clinical symptoms and water quality performed as preliminary data on the determination of KHV infection in carp.

\section{DNA extraction}

Fish gill that suspected as infected with KHV virus is cut into small pieces/finely crushed, inserted into a sterile Eppendorf tube and added 1 $\mathrm{mL}$ of Tri-Reagent. Tri Reagent tissue and solution are homogenized using pellet pastel, incubated at room temperature for 5 minutes and then centrifugate at $14,000 \mathrm{rpm}$ at room temperature for 5-10 minutes. After centrifugation, collect $200 \mu \mathrm{L}$ of the supernatant and inserted into new Eppendorf tube. Then, $0.5 \mathrm{~mL}$ of $100 \%$ alcohol is added to homogeneous and centrifuged at 10,000 rpm, at room temperature for 5 minutes.

The supernatant then eliminated and the pellet washed by adding $1 \mathrm{~mL}$ of $70 \%$ alcohol and centrifuged at $10,000 \mathrm{rpm}$, at room temperature for 5 minutes. This method was repeated three times or until the color of yellowish pigment disappears. For the last step, remove the superna- tant and dry the pellet of DNA using aerated and dissolved with $\mathrm{dd}_{2} \mathrm{O}$ or Nuclease-Free Water by $25 \mu \mathrm{L}$ and immediately followed by amplification [12].

\section{PCR Test}

KHV tested using PCR test after DNA from fish tissue extracted and determined its concentration. PCR amplification using primer Thymidine kinase [10] with its forward base 5'GGGTTACCTGTACGAG-3' and reverse 5'CACCCAGTAGATTATGC-3' with target band of $409 \mathrm{bp}$ (based pairs). The process of amplification begins with the initial denaturation at $95^{\circ} \mathrm{C}$ for about 5 minutes ( 1 cycle), and then 30 cycles of amplification consists denaturation at $95^{\circ} \mathrm{C}$ for about 30 seconds, annealing at the temperature of $50^{\circ} \mathrm{C}$ for about 30 seconds and extension at the temperature of $72^{\circ} \mathrm{C}$ for about 30 seconds, terminated with extra elongation at $72^{\circ} \mathrm{C}$ for about 7 minutes ( 1 cycle).

After the amplification process completed, $10 \mu \mathrm{L}$ of every sample taken (as well as the marker) then added $2 \mu \mathrm{L}$ of staining solution ( $6 \mathrm{x}$ loading dye) and mixed well on the parafilm. Ten microliters of the sample mixture are inserted into each well on the agarose slowly and carefully. Electrophoresis is carried out with electric power of $100 \mathrm{~V}, 400 \mathrm{~mA}$ for 25 minutes. Immerse the gel in the buffer that added with $0.05 \%$ ethidium bromide (EtBr) for 15 minutes. The gel is placed on the gel documentation to observed and documented [12].

\section{DNA Sequencing}

Positive PCR product contains DNA KHV packed for sequencing. Sequencing done at First Base Laboratories (molecular biology service) Malaysia.

\section{Data analysis}

PCR test results in KHV-positive fishes presented in the form of a picture. Furthermore, the sequenced data are analyzed and edited using the Bioedit [13]. The sequence consensus result is matched with the sequence in GenBank NCBI (National Center for Biotechnology Information) available online through the BLAST (Basic Local Alignment Search Tool) method. Then, using computer software MEGA ver. 3 in align with the data from GenBank assisted using Clustal W computer software [14]. The construction of phylogenetic trees is determined using NeighbourJoining (NJ-tree) method [15]. 


\section{RESULT AND DISCUSSION}

The presence of the virus within the host cell can determinated through the appearance of clinical symptoms or abnormalities in the infected host organ. According to the visual observation of KHV-infected fishes show the increasing of respiratory disorder frequency behavior, swimming toward the water surface, or gathering at the water surface, and weak movement. Observation of the external disorder of some infected fishes show the presence of bleeding and wound on the fish's body, erosion of the gill, color of the gill and pale body and excessive mucus secretion (Fig. 1 and 2).

Clinical symptoms of KHV are often not specific and causes mortality attack in 24-40 hours subsequently. Another study showed that KHV infection causes gill erosion and the appearance of pale, lethargy (fish's mouth always pointing out to the surface), sunken eyes, excessive mucus secretion, discoloration, fish skin peeling and Increased respiratory rates $[16,17]$. The main clinical symptom of KHV is skin peeling, pale and necrotic of skin and gill [18].

Fish gill damage showed by behavioral disorder such as always swim and gather at the surface or gather at the water surface and increase respiratory frequency, meanwhile, damage of the brain and fish nervous system showed by the aimless movement where both organs are the target of KHV $[1,17,19,20]$.

The symptom of excessive mucus secretion is one of the fish's body-protection responses to the invasion of pathogenic agents including KHV and its environmental change. Mucus in the skin found in the epidermis layer that serves as the body's defense of fish. Moreover, in the epidermal layer, there are also cells that can migrate freely such as lymphocytes and macrophages that play a role in skin immunity and in the epidermal layer, that cells secrete immunoglobulin into the skin mucus $[21,22]$.

Other symptoms found on the fish's body surface are bleeding and skin wound. Bleeding symptom occurs due to the rupture of the blood vessel. In the artery or vein, it can caused by several things such as trauma, inflammation, or erosion of blood vessel wall. Wound or skin damage can caused by the rough treatment and ectoparasitic infestation resulting in elevated sensitivity to secondary infection. Some ectoparasites causes of skin abrasion, although it's not severe, the wound can be the entrance of infectious agents [21].
Water temperature has a role in disease attack in aquatic animals such as being able to increase viral replication in the host while suppressing host immune processes [23]. The most definitive factor affecting KHV virulence is water temperature [19]. That carp lives in the temperature range between $18-30^{\circ} \mathrm{C}$ and grow optimum between $20-28^{\circ} \mathrm{C}$ [24]. Water temperature at the study site showed at Figure 3.

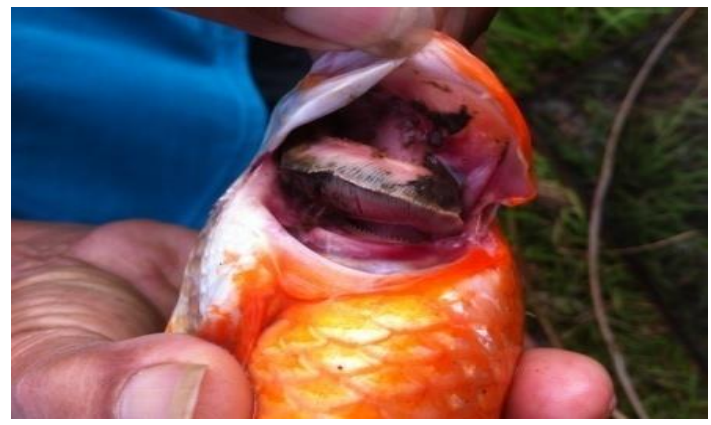

Figure 1. The Carp's Gill Infected with KHV are Eroded and Appear Pale

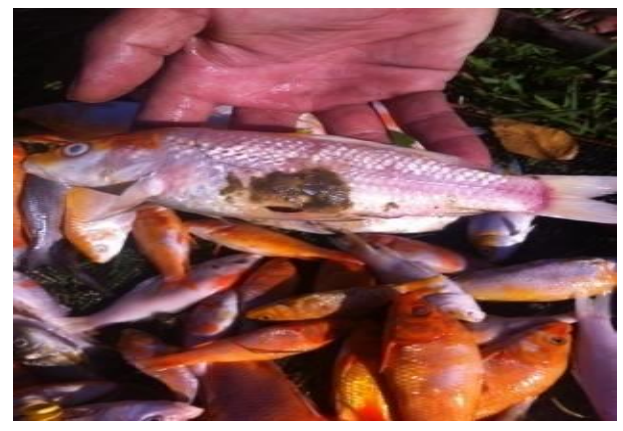

Figure 2. Hemorrhagic and Wound on the Surface of the Fish Body

Optimal temperature of KHV development that can cause death is between $18-27^{\circ} \mathrm{C}$. This factor also has something to do with the change of seasons either from the rainy season to the dry season or vice versa, which play a role in the incidence of KHV disease [1].

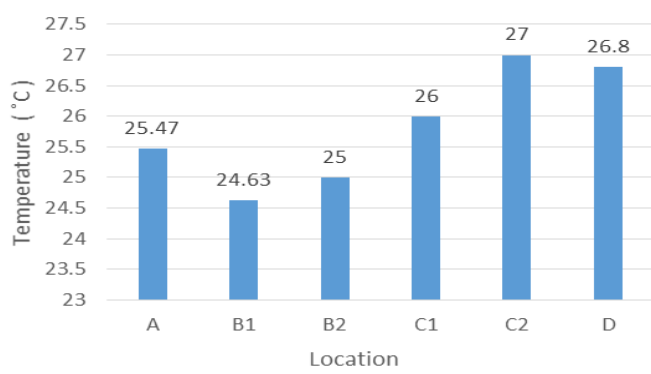

Figure 3. The Temperature at the Study Site. Highest temperature was West Lombok (C2) at $27^{\circ} \mathrm{C}$ and lowest temperature was East Lombok (B1) at $24.63^{\circ} \mathrm{C}$. Description: $A=$ Mataram, $B 1=$ East Lombok, B2= East Lombok, C1= West Lombok, $\mathrm{C} 2=$ West Lombok, $\mathrm{D}=$ Central Lombok. 
PCR test performed to ensure that fish test was infected by KHV. The samples that show specific clinical symptoms from one study site was collected and then extracted. Furthermore, they are amplified to produce 409 bp PCR product. The final result obtained KHV positive results of 5 samples representing each location (Table 1).

\begin{tabular}{llcl}
\multicolumn{4}{c}{ Table 1. Results of PCR } \\
\hline No & Region & Location & Result of PCR \\
\hline 1. & Mataram & UPR (A) & Positive KHV \\
2. & East Lombok & BPBIAT (B2) & Positive KHV \\
& & UPR (B2) & Positive KHV \\
3. & West Lombok & UPR (C1) & Positive KHV \\
& & UPR (C2) & Negative KHV \\
4. & Central Lombok & UPR (D) & Positive KHV
\end{tabular}

Note: the PCR test of fish sample with clinical symptom of KHV showed that five was positively infected.

PCR method used in this study proof the presence of KHV in carp, even long after the outbreak. This PCR test [10] where he conducted a research on cloning of the Thymidine kinase gene and state that Thymidine kinase as a standard method to diagnose KHV. PCR test using Thymidine kinase to detect at least 10 femtogram of KHV DNA against 30 virions, while the PCR method by previous study $[17,20]$ used the primary design of the of fragment sequence of DNA restriction at the non-coding region of DNA virus. Its may not match the KHV strain, so the result is undetectable [25].

Accordingly, suggests that PCR using the primary design of the thymidine kinase gene of the KHV genome has higher sensitivity than the two previous methods. Based on the result of the test using PCR method, Electrophoresis gel visualization showed the DNA band banding, the positive result obtained by 409 bp band or parallel to the positive control (Fig.4).

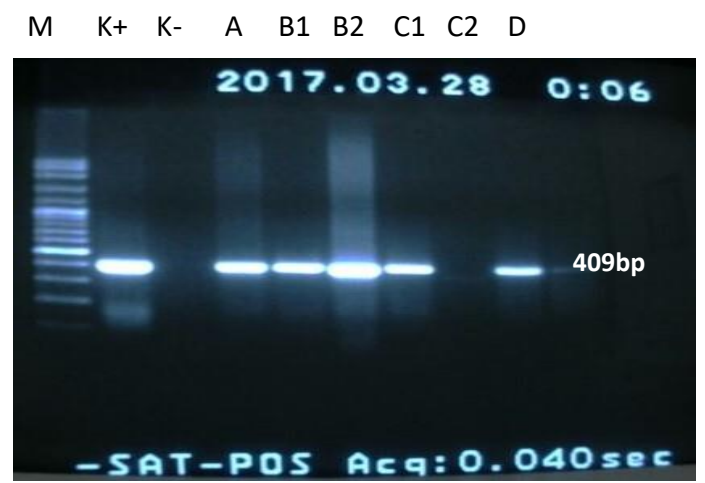

Figure 4. Results of Electrophoresis Visualization of the fish sample suspected to be attacked by KHV. Description: $\mathrm{M}=$ Marker $100 \mathrm{bp}, \mathrm{K}+=$ Positive Control, $\mathrm{K}-=$ Negative Control, $\mathrm{A}$ to $\mathrm{D}=$ Gill Sample.
The result of DNA sequencing from the KHVinfected fish template in the form of the nucleotide sequence (adenine, cytosine, guanine, and thymine) are later used to determine the percentage of the similarity between isolate genotypic examined based on the database GenBank. Isolated KHV from GenBank can be used as the reference for related analysis with genomic data from the existing isolate to predict the evolution speed that occurs and to be reconstructed by the evolutionary relationship between one organism and another.

Based on the multiple alignments (Fig. 5) it can be said that KHV isolate from the Lombok Island has high homology with all four isolates comparatively. Another study reported that phylogenetic analysis using the same methode indicate that isolate of MG, CK and VK (from Indonesian) had close relations of association with KHV strain $\mathrm{J}$ isolates and of variant $\mathrm{A} 1$ of Asian genotype, whereas KV3 isolates have a close relationship of kinship with the $U / I$ strain KHV isolate and the variant E1, E2, E3 of European genotype [26].

Genetic variation in the virus is one natural way to adapt to environmental changes. Viruses must face its change constantly in their host, as well as passing from one host to another. They must deal with a defense response or immune system of the host. Avoiding the host defense is a central feature of the defensive strategy in all viruses [8].

Mutation can happened at anytime in the growth of a virus population. It may occur spontaneously or may be induced by physical and chemical agents against the DNA. The spontaneous may result from inter-pair faults during DNA replication or during reparation of the DNA. Also, it can occur due to meaningless changes in the DNA base, low radiation level, the bases in depuration or deamination or recombination that spontantly change [8].

With regards to genetic analysis of KHV obtained from DNA sequencing and phylogenetic tree construction (Fig. 6), it can illustrated how the relationship between DNAKHV from various locations and can predict the possibility of the outbreak. Sample isolate has a relatively high or very high resemblance, may come from the same source. The increasing inter-regional carp trade in the Lombok Island region or between provinces bring the possibility of spreading the KHV variants that previously found in another location.

A study reported that on isolation and characterization of the first KHV isolates from koi 
and carp in Indonesia [4]. Clinical symptoms, morphology, histopathology, and thevirions are similar from other countries. Phylogenetic analyses using the thymidine kinasegene from each collected samplesfrom KHV outbreaks throughout Indonesia suggest that Indonesia's are closer to KHV Asian offspring than in Europe [4].

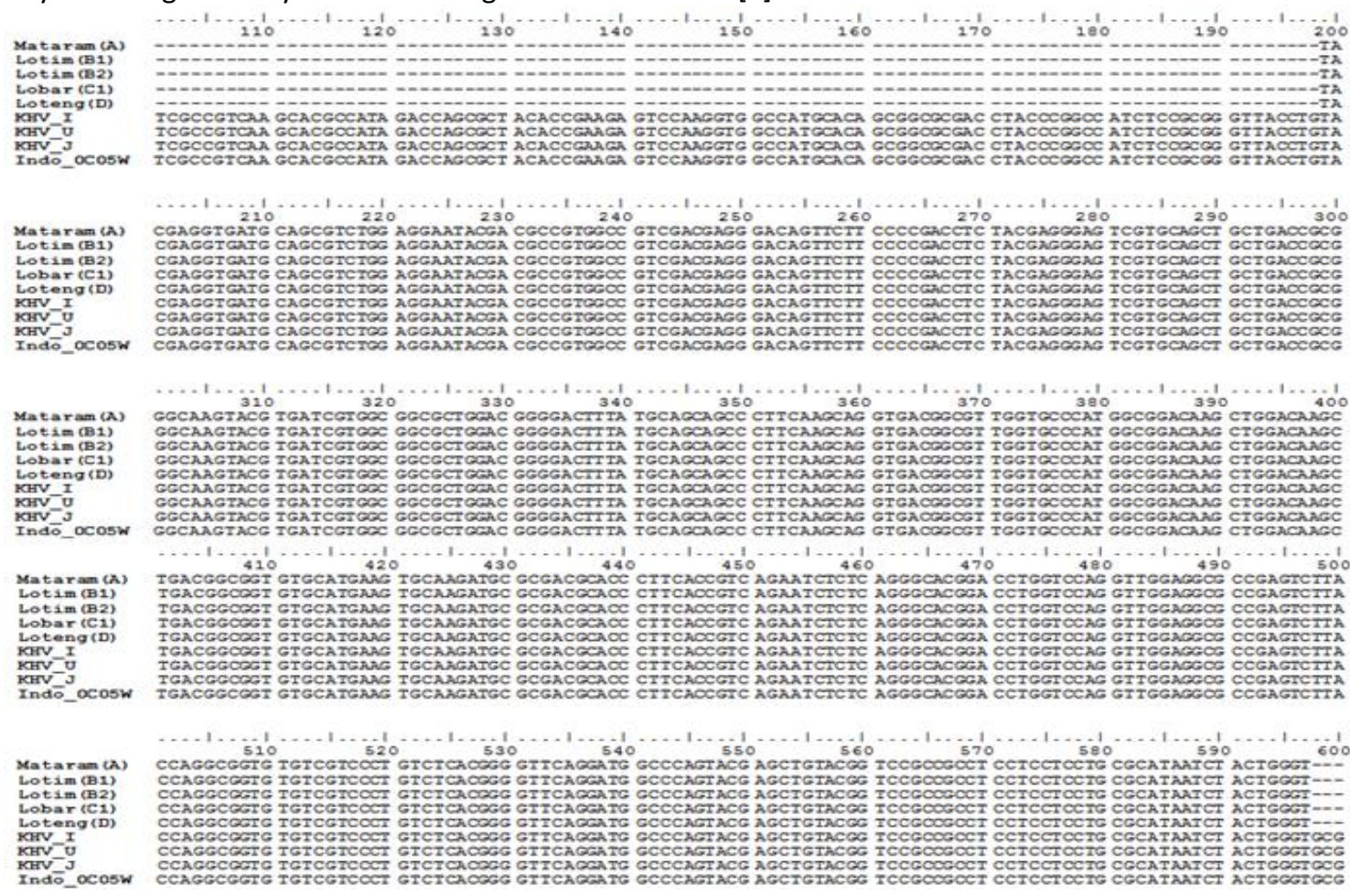

Figure 5. The Result of Multiple Alignments

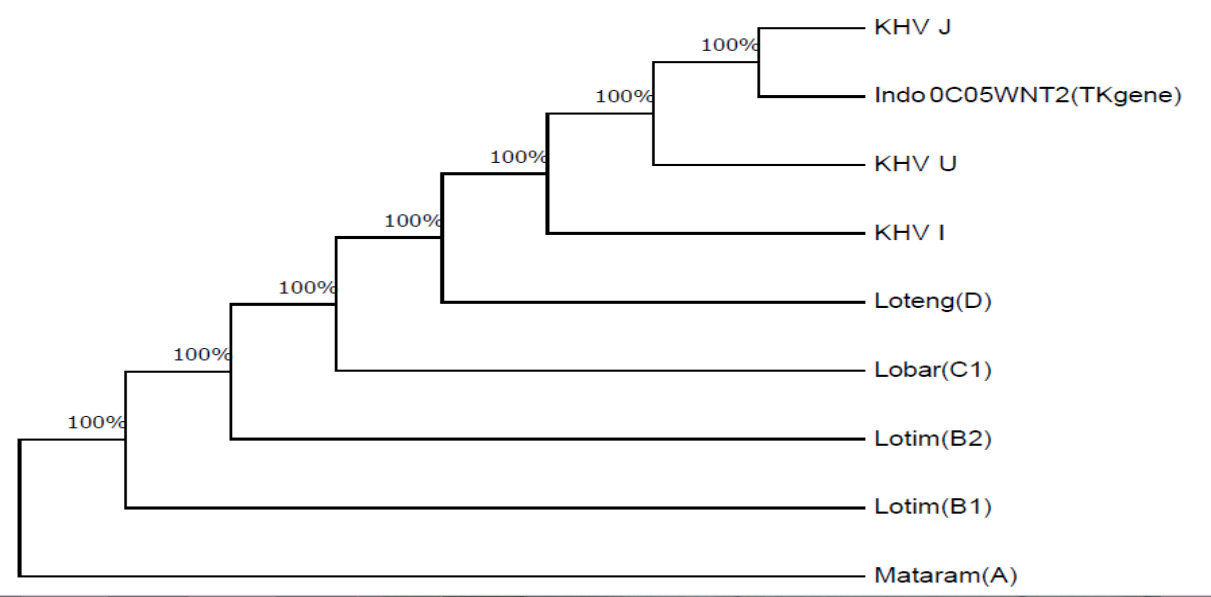

Figure 6. Construction of KHV Isolate Phylogenetic Tree and Comparative Isolate by Neighbors-Joining Method

\section{CONCLUSION}

The research shows that clinical symptoms that appear are the pale grill and bleeding on the surface of the body. The results electrophoresis of carp suspected with KHV shows five positives out of a total six samples. Genetically, KHV isolates from Lombok Island of West Nusa Tenggara Province is identical with the GenBank isolate code $\mathrm{KHV}-\mathrm{J} / \mathrm{U} / \mathrm{I}$ and Indo_OCO5WN.

\section{REFERENCES}

[1] Hedrick, R.P., O. Gilad, S. Yun., J.V. Spangenberg, G.D. Marty, R.W. Nordhausen, M.J. Kebus, H. Bercovier, A. Eldar. 2000. A herpesvirus associated with mass mortality of juvenileand adult koi, a strain of common carp. J. Aquat. Anim. Health. 12. 44-57. 
(Baihani, et al.)

[2] Bretzinger, A., T. Fischer-Scherl, $M$. Oumouma, R. Hoffmann, U. Truyen. 1999. Mass mortalities in Koi, Cyprinus carpio, associated with gill and skin diseases. Bull. Eur. Assoc. Fish Pathol. 19(5). 182-199.

[3] Hedrick, R.P., G.D. Marty, R.W. Nordhausen, M.J. Kebus, H. Bercovier, A. Eldar. 1999. A herpesvirus associated with mass mortality of juvenile and adult Koi Cyprinus carpio. Fish Health Newsletter, Fish Health Section. American Fisheries Society. California. 12. 44-57.

[4] Sunarto, A., Taukhid, A. Rukyani, I. Koesharyani, H. Supriyadi, L. Gardenia, H. Huminto, D.R.A. Priyono, F.H. Pasaribu, Widodo, D. Herdikiawan, D. Rukmono, S.B. Prayitno. 2005. Field investigations on a serious disease outbreak among koi and common carp (Cyprinus carpio) in Indonesia. In: Walker, P.J., R.G. Lester, M.G. Bondad-Reantaso (Eds). Diseases in Asian Aquaculture V. Fish Health Section, Asian Fisheries Society, Manila, Philippines. 125136.

[5] Sunarto, A. 2004. Epidemiologi penyakit koi herpesvirus (KHV) di Indonesia. Laboratory of Fish Health Research, Research Center of Marine and Fisheries. Jakarta.

[6] Ministry of Marine and Fiheries. 2015. Decision No. 81/KEPMEN-KP/2015. Penetapan area yang tidak bebas penyakit ikan karantina, golongan, dan media pembawanya di wilayah negara Republik Indonesia. Ministry of Marine and Fiheries. Jakarta.

[7] BKIPM Mataram. 2016. Annual Repport 2016. Fish Quarantine Station of Quality Control and Safety Fishery Products Class II. Mataram.

[8] Walker, P.J. 2000. Introduction of virology. CSIRO Tropical Agriculture, Indooroopilly, Queensland, Australia.

[9] Ilouze, M., A. Dishon, T. Kahan, M. Kotler. 2006. Cyprinid herpes virus-3(CyHV-3) bears genes of genetically distant large DNA viruses. FEBS. Lett. 580. 4473-4478.

[10] Bercovier, H., Y. Fishman, R. Nahary, S. Sinai, A. Zlotkin, M. Eyngor, O. Gilad, A. Eldar, R.P. Hedrick. 2005. Cloning of the koi herpesvirus (KHV) gene encoding thymidine kinase and its use for a highly sensitive PCRbased diagnosis. Bio. Med. Central Microbiol. 5. 13.

[11] Aoki, T., I. Hirono, K. Kurokawa, H. Fukuda, R. Nahary, A. Eldar, A.J. Davidson, T.B. Waltzek, H. Bercovier, R.P. Hedrick. 2007.
Genome sequences of three Koi herpesvirus isolates representing the expanding distribution of an emerging disease threatening koi and common carp worldwide. J. Virol. 5058-5065.

[12] Fish Quarantine Center. 2008. Metode standar pemeriksaan HPIK golongan virus Koi Herpesvirus (KHV). Puskari Publisher. Jakarta.

[13] Hall, T.H. 1999. Bioedit: a user-friendly biological sequence alignment editor and analysis program for Windows 95/98/NT. Nucleic Acid Symp. Ser. 4. 95-98.

[14] Thompson, J.D., D.G. Higgins, T.J. Gibson, 1994. W: Improving the sensitivity of progressive multiple sequence alignment through sequence weighting, position specific gap penalties, and weight matrix choice. Nucleic Acids Res. 22. 4673-4680

[15] Nei, M. 1987. Molecular evolutionary genetics. Columbia University Press. New York.

[16] Bondad, M.G. 2002. Transboundary aquatic animal disease focus on Koiherpesvirus (KHV). Aquatic Animal Research Pathologist at the Cooperative Oxford Laboratory of the Maryland, Dept. Natural Resources in Oxford. Maryland.

[17] Gray, W.L., L. Mullis, S.E. LaPatra, J.M. Groff, A. Goodwin. 2002. Detection of koi herpesvirus DNA in tissues of infected fish. J. Fish Dis. 25. 171-178.

[18] Oh, M.J., S.J. Jung, T.J. Choi, R. Kim, K.V. Rajendran, Y.J. Kim, M.A. Park, S.K. Chun. 2001. A viral disease occurring in cultured carp Cyprinus carpio in Korea. Fish Path. 36. 147-151.

[19] Gilad, O., S. Yun, M.A. Adkison, K. Way, N.H. Willits, H. Bercovier, R.P. Hedrick. 2003. Molecular comparison of isolates of an emerging fish pathogen, koi herpesvirus, and the effect of water temperature on mortalityof experimentally infected koi. J. General Virol. 84. 2661-2668.

[20] Gilad, O., S. Yun, F.J.Z. Vergara, C.M. Leutenegger, H. Bercovier, R.P. Hedrick. 2004. The Concentration of koi herpesvirus (KHV) in tissues of experimentally infected Cyprinus carpio koi as assessed by real-time TaqMan PCR. Dis. Aquat. Organ. 60. 179187.

[21] Roberts, R.J. 2001. Fish Pathology, $3^{\text {rd }}$ Ed. W.B. Saunders. London.

[22] Takashima, F., T. Hibiya. 1995. An atlas fish histology, normal and pathological features, 
$2^{\text {nd }}$ Ed. Kodansha Ltd. Tokyo. Pathological features, $2^{\text {nd }}$ Ed. Kodansha Ltd. Tokyo.

[23] Alcorn, S.W., Al Murray, J.R. Pascho. 2002. Effect on rearing temperature on immune function in sockeye salmon Oncorhynchus nerka. Fish Shellfish Immunol. 12. 303-304.

[24] Serdiati, 1988. Pengaruh padat penebaran terhadap pertumbuhan ikan mas (Cyprinus carpio) yang dipelihara dalam keramba pada kolam dengan input air limbah rumah tangga. Bachelor Thesis. Faculty of Animal Husbandry. Hasanuddin University. Makassar.

[25] Haenen, O.L.M, K. Way, S.M. Bergmann, E. Ariel. 2004. The emergence of koi herpesvirus and its significance to European aquaculture. Bull. Eur. Ass. Fish. Pathol. 24. 293-307.

[26] Pratiwi, G. 2016. Analisis variasi genotip dan filogenetik koi herpesvirus di Indonesia berdasarkan dua penanda molekuler dan sekuen gen thymidine kinase. Bachelor Thesis. Faculty of Fisheries. Gajah Mada University. Yogyakarta. 